\title{
Jacek Szmagliński
}

Dr inż.

Politechnika Gdańska

jacszmag@pg.edu.pl

DOI: 10.35117/A_ENG_19_10_01

\section{Analysis of geometrical layout of tram tracks based on the railway methods}

\begin{abstract}
The paper describes problems occurring during travelling by trams over curves. It was determined that stong jerks occur as a result of the lack of analysis of kinematic parameters on curves and changes in the construction scheme of trams. A proposal for a computational methodology has been given. Calculations of kinematic parameters were carried out for typical geometric layouts in accordance with the Polish Guidelines.
\end{abstract}

Keywords: Tram rails; Motion kinematics; Comfort and safety

\section{Introduction}

In recent years, an accelerated process of replacing worn-out tram rolling stock with modern, low-floor constructions can be observed in Poland. The wagons are not always brand new, very often they are used vehicles, factory low-floor or rebuilt from high-floor as part of modernizations. Most low-floor trams currently operating in Poland were produced according to the construction scheme, developed since the development of the Siemens Combino tram $[14,15]$ (50.4\% at the end of 2018, a decrease from 54.3\% at the end of 2016). Besides, in new orders (at the beginning of 2019) such constructions constitute 71.2\%. Undoubtedly, Warsaw is the leader when it comes to low-floor trams, both in terms of the number of such trams (281) and their share in the low-floor fleet (90.7\%). In the case of producers, Pesa is the most popular with its Tramicus, Swing and Jazz trams which constitute $78.2 \%$ of the trams with the structure described above in Poland. These trams consist of an odd number of components $(3,5,7)$, of which the outer and middle sections are rigidly supported on the bogie. The even members are based on both sides on the odd members. This design allowed to obtain (at low purchase and operating costs) vehicles with a fully low floor, which undoubtedly contributed to their definite advantage over other constructions.

Simultaneously with the purchase of new vehicles, repairs and modernizations of existing tram routes are carried out. Thanks to these actions, local speed limits resulting from the poor condition of the surface have been eliminated. This allows trams to develop full speeds on inter-route sections and thus, reduce driving time.

However, it has been noted that despite the improvement of both rolling stock and railroad track, passengers complain that the new trams experience significantly greater jerks when passing through the curves. Most often it is explained that multi-articulated trams based on rigid bogies are by definition very uncomfortable vehicles and passengers have to get used to the inconvenience associated with travel. Meanwhile, similar trams are successfully running on the tracks in France, where they are considered as very comfortable means of transport. This is a premise to determine the thesis that the reason for the disturbance of comfort when traveling by low-floor trams in Poland is the mismatch of track infrastructure design methods to modern tram vehicles. This means that it is necessary to develop methods that enable the assessment of real kinematic conditions occurring on geometrical systems and proposals for adapting them to changing wagons and increasing speed.

For this purpose, an analysis of typical geometric systems found on tram tracks in Poland was performed, using the theory popular in rail transport. 


\section{The rigid base method in the rail transport}

During the analysis of railway geometrical systems, the method of analyzing kinematic parameters is commonly used. It assumes modeling of the vehicle using a material point $[3,9$, 10]. The material point is believed to be in one of three states:

- uniform linear motion (motion model along a straight line),

- uniform motion in the constant curvature (arc motion model),

- uniform motion in the variable curvature (motion model along a transition curve).

The acceleration values in the horizontal plane, perpendicular to the track axis, are determined for each state. For the movement of a material point in the arc, the value of lateral acceleration is:

$$
a=\frac{V^{2}}{12,96 \square R}
$$

The acceleration increase over time, along the length of the transition curve, with a linear increase in curvature connecting the straight line with the arc, is determined based on the relationship:

$$
\frac{d a}{d t}=\frac{V^{3}}{46,656 R L}
$$

The basic deviation from treating the vehicle as a material point is the train movement pattern along with the cant. In this case, the passenger is treated as a material point. The acceleration value $\left(\mathrm{a}_{\mathrm{x}}\right)$, affecting the passenger in the vehicle, depends on the tilt of the wagon body on the cant $(\alpha)$ and the value of gravity $\left(\mathrm{a}_{\mathrm{g}}\right)$ and centripetal acceleration $\left(\mathrm{a}_{\mathrm{d}}\right.$, calculated as for the material point model). Figure 1 shows the states in which a moving vehicle may be located. Scheme A shows a vehicle moving in a curve without cant, Scheme B - a vehicle traveling in a straight section with a cant, Scheme $\mathrm{C}$ moving in a curve with a cant.
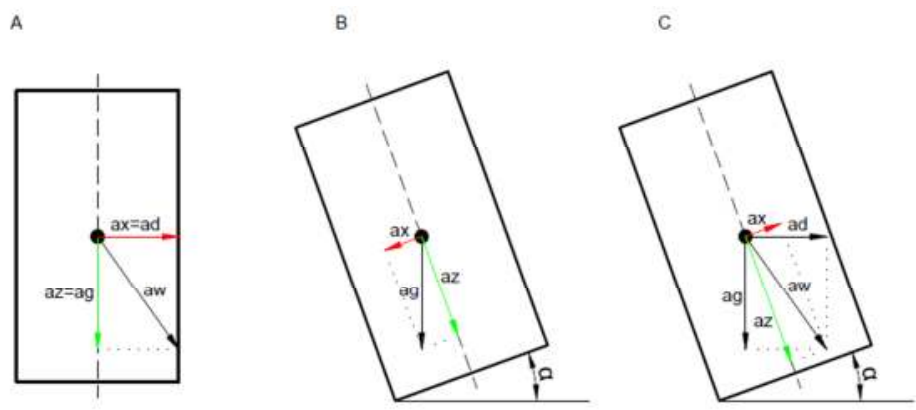

1. The idea of calculating resultant acceleration affecting a passenger

The acceleration $a_{x}$ is called the unbalanced acceleration and its value is calculated according to the dependence:

$$
a_{x}=\frac{V^{2}}{12,96 R}-\frac{g D}{s}
$$

The relationship between the curvature, cant, and acceleration on an arc with transition curves is shown in Figure 2. The value of the increase of unbalanced acceleration in time, along the length of the transition curve, with a linear increase in curvature, connecting the straight line with the curve, with a cant ramp with ordinates increasing in line with increasing linear curvature is described by the following formula: 


$$
\frac{d a_{x}}{d t}=\frac{V\left(\frac{V^{2}}{12,96 R}-\frac{g D}{s}\right)}{3,6 L}
$$

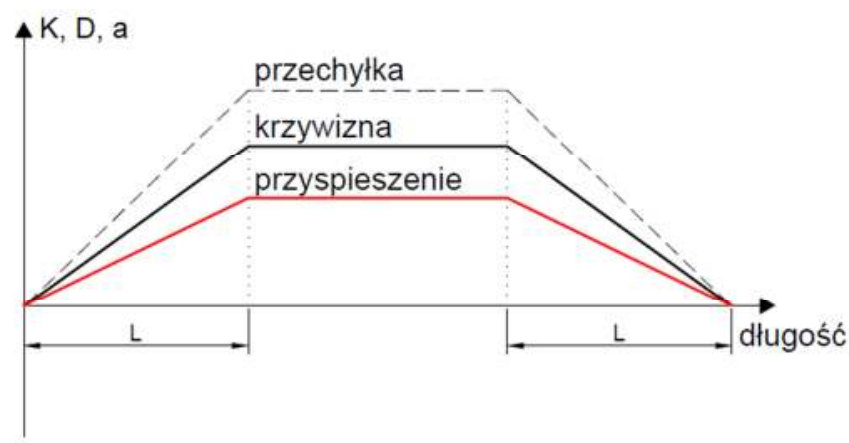

2. Diagram of the variability of parameters on an arc with transition curves

The second reason for moving away from treating a vehicle as a material point occurs during the analysis of systems consisting of tangent connections of arches with straight lines (connection without transition curve). In railway transport, such cases most often occur at switches and station track systems, where the arches are made without cant. It is assumed that the acceleration increase will occur along the length between the bogie pivots (constituting the so-called rigid base of the wagon) [3, 10]. For a typical passenger car, the length of the rigid base is $20 \mathrm{~m}$. The value of the acceleration increase over time, along the length of the rigid base of the wagon, is described by the following formula:

$$
\frac{d a}{d t}=\frac{V^{3}}{46,656 R L_{b}}
$$

In addition to accelerations, the cant increment over time (wheel rise speed over the rail) and cant increment over the length (steepness of the cant ramp) are determined along the length of the cant ramps. The values for a rectilinear cant ramp with a length equal to the length of the transition curve are calculated based on the following relationships:

$$
\begin{aligned}
\frac{d D}{d t} & =\frac{V D}{3,6 L} \\
\frac{d D}{d s} & =\frac{D}{L}
\end{aligned}
$$

The calculated values are then compared with the allowable values and on this basis, it is determined whether the project was carried out correctly. To consider a geometric system to meet the assumptions, the following relationships must be true:

$$
\begin{aligned}
& -a_{t} \leq a_{x} \leq a_{d o p} \\
& \left|\frac{d a_{x}}{d t}\right| \leq\left(\frac{d a}{d t}\right)_{d o p} \\
& \frac{d D}{d t} \leq\left(\frac{d D}{d t}\right)_{d o p} \\
& \frac{d D}{d s} \leq\left(\frac{d D}{d s}\right)_{d o p}
\end{aligned}
$$

Due to the significant differences in the construction of tram and railway wagons and different track widths, it was decided to analyze kinematic parameters using the acceleration method. The use of this approach, in contrast to cant deficiency, significantly facilitates the analysis, as there is no need to create a large number of variants of acceptable parameters. 
This particularly applies to the permissible value of a sudden change of cant deficiency, which value must reflect both track and rolling stock parameters.

\section{Geometric layouts on the tramways}

Currently, in Poland, tram routes are designed based on the provisions appearing in Regulation [4] and the Technical Guidelines [7]. The ordinance concerns the design of tram tracks situated in the width of the road lane and gives only limit parameters for horizontal and vertical arches and longitudinal inclination. There is no requirement to use kinematic parameter analyzes as well as no limit parameters. This is a significant impediment to assessing the quality of the project, in terms of comfort and safety as well as the operational durability of the rail surface. For this reason, infrastructure managers recommend that designers use the provisions of the Technical Guidelines. This document is an optional obligation to extend the entries in the Regulation. It is recommended to use curves with a larger radius (on the route $150 \mathrm{~m}$ instead of a minimum of $50 \mathrm{~m}$ ), which was to enable the passage of trams without reducing the speed on the curves. At the same time, an analysis of kinematic parameters is still not required, the designer can use a table in which cant values have been determined for specific values of arc radius and travel speed. The design of straight connections with arches has also been greatly simplified. Designing transition curves is not required for arches over $100 \mathrm{~m}$ in radius, while the design for arches with smaller radii is maximally simplified. The transition curve in the form of tangent arcs with gradually decreasing radii is most commonly used.

Alternatively, the guidelines recommend the design of transition curves in the form of the third-degree parabola, described by the equation:

$$
y=\frac{x^{3}}{6 c}
$$

where $\mathrm{c}$ is a constant parameter of the value of $250-1000$, and the length of the transition curve is calculated from the relationship:

$$
L=\frac{C}{R}
$$

It is clear that the length of the transition curve, determined according to the method presented in the Guidelines, does not depend on kinematic parameters, but only on the arc radius and the arbitrarily chosen parameter $\mathbf{c}$ (the Guidelines do not specify on what basis the value of this parameter should be selected).

The method of designing cant ramps has been adopted completely separately, for which the only parameter analyzed is the ramp inclination. They need not be in any way related to the length of the transition curves or the speed of the trams traveling on the track. A slightly different approach is shown in the Interim Guidelines [8], which were developed in the early eighties. The document recommends that the transition curve should be related to the length of the cant ramp. The length of the ramp was calculated in the same way as in the railway case, however, the value of the maximum cant increase speed in time was not given, but only a ready formula for the length of the ramp:

$$
L=10 \vee D
$$

The lack of requirement in the document for assessing the speed of acceleration increase over time may lead to the use of systems without transition curves in the case of arches without cant. However, interim guidelines have never become widespread due to the halting of tram investments in the early 1980s recession. Currently, managers rarely refer to the provisions of this document due to difficult accessibility. 
It is clear that although trams are part of a group of rail vehicles, the approach to tramway design is different from that of railways. Inadequately formulated design assumptions lead to the widespread use of simplified systems, without transition curves and with cant ramps located on straight sections. They are one of the sources of the common belief in Poland that trams are an uncomfortable means of transport because passengers overcome curves experience unpleasant jerks.

\section{Calculations of kinematic parameters on tram systems}

During research conducted on tram rails $[5,6,11]$ it was determined that the most common geometric layout in Gdańsk, where the direction of the route is changed, is a system without transition curves (over 75\% of cases), without cant on the arch (analogous to the one occurring on railway tracks) or with cant (typical for tram tracks). Figure $\mathbf{3}$ shows the analysis of the acceleration variability course, adopts the principle of determining acceleration increases according to the rigid base method of the wagon.

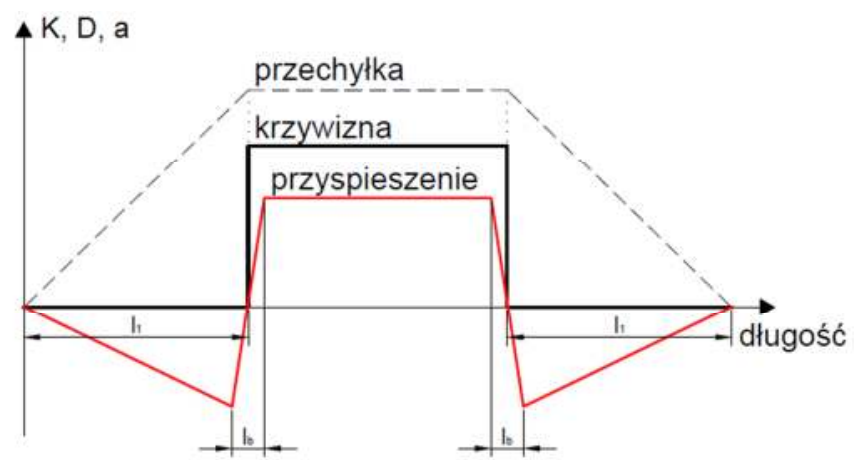

3. Diagram of parameter variability on a cant curve without transition curves

Maintaining the required high ride comfort on such a geometric layout requires that the relationships shown in formulas (8-11) are met. The dependencies regarding the cant increments depend on the speed and the length of the cant ramp, so they are analogous to those in the railway case. The relationship regarding the increase in unbalanced acceleration is different. The value of the acceleration increase in two intervals should be checked, along the length of the cant ramp and in the place where the straight line with the arc is connected. On the cant ramp, the acceleration will result from the occurrence of straight line motion with the cant (according to figure 1B) and will be directed in the opposite direction to the acceleration on the circular arc (in the absence of excess cant on the curve). For this reason, the increase in acceleration over time along the length of the ramp is determined by the following relationship:

$$
\left(\frac{d a_{x}}{d t}\right)_{r}=\frac{V g D}{3,6 s L_{r}} \leq\left(\frac{d a}{d t}\right)_{d o p}
$$

And the acceleration gain at the connection of the straight line with the arc, along the length of the rigid base of the wagon:

$$
\left(\frac{d a_{x}}{d t}\right)_{b}=\frac{V \Delta a_{x}}{3,6 L_{b}}=\frac{V\left(\frac{V^{2}}{12,96 R}-\frac{g D}{s}+\frac{g D}{s}\right)}{3,6 L_{b}}=\frac{V^{3}}{46,656 R L_{b}} \leq\left(\frac{d a}{d t}\right)_{d o p}
$$

The transformation presented above shows that the value of acceleration increase over time, along the rigid base of the wagon, with the tangent connection of the straight line with the arch, does not depend on the value of the cant on the arch. 
Among the systems with transition curves, there are also systems in which the lengths of cant ramps are associated with the lengths of the transition curves (system compatible with railway solutions, Fig. 2) and systems with transition curves not related to cant ramps. The system may consist of a transition curve in the form of a third-degree parabola and a longer rectilinear cantilever ramp that overlaps both the straight section and the circular arc. The relationship between cant, curvature, and acceleration on such a system is shown in Figure 4.

General relationships allowing the calculation of kinematic parameters were determined. The maximum value of centripetal acceleration on a straight section with a cant is:

$$
a_{x}=\frac{g D L_{1}}{s\left(L_{1}+L_{2}+L_{3}\right)} \leq a_{t}
$$

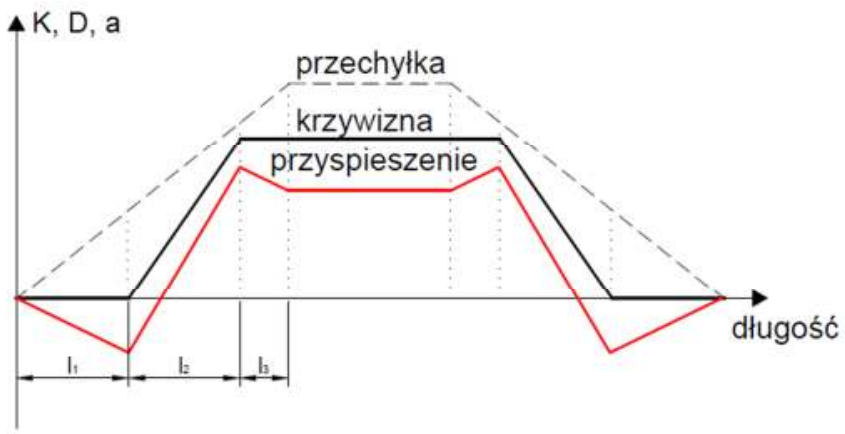

4. Diagram of the variability of parameters on an arch with cant and transition curves with a length not related to the length of the cant ramp

The maximum value of unbalanced centrifugal acceleration is:

$$
a_{x}=\frac{V^{2}}{12,96 R}-\frac{g D\left(L_{1}+L_{2}\right)}{s\left(L_{1}+L_{2}+L_{3}\right)} \leq a_{\text {dop }}
$$

On the length of the cant ramp overlapping the straight section and the $\operatorname{arc}\left(\mathrm{L}_{1}\right.$ and $\left.\mathrm{L}_{3}\right)$, there is an identical value of acceleration increase over time, determined by the relationship:

$$
\left(\frac{d a_{x}}{d t}\right)_{r}=\frac{V g D}{3,6 s\left(L_{1}+L_{2}+L_{3}\right)} \leq\left(\frac{d a}{d t}\right)_{\text {dop }}
$$

There is an increase in acceleration in time over the length of the transition curve:

$$
\left(\frac{d a_{x}}{d t}\right)_{k p}=\frac{V^{3}}{46,656\left\ulcorner R L_{2}\right.}-\frac{V g D}{3,6 s\left(L_{1}+L_{2}+L_{3}\right)} \leq\left(\frac{d a}{d t}\right)_{d o p}
$$

The above relationships are universal and can be used for any system where the lengths $\mathrm{L}_{1}$ and $\mathrm{L}_{3} \mathrm{can}$ be equal to zero. The second case of an arc with transition curves with lengths not related to the length of the cant ramps occurs in the case of a transition curve designed using a series of arches with gradually decreasing radii. The relationship between cant, curvature, and acceleration on such a system is shown in the Figure $\mathbf{5}$. 


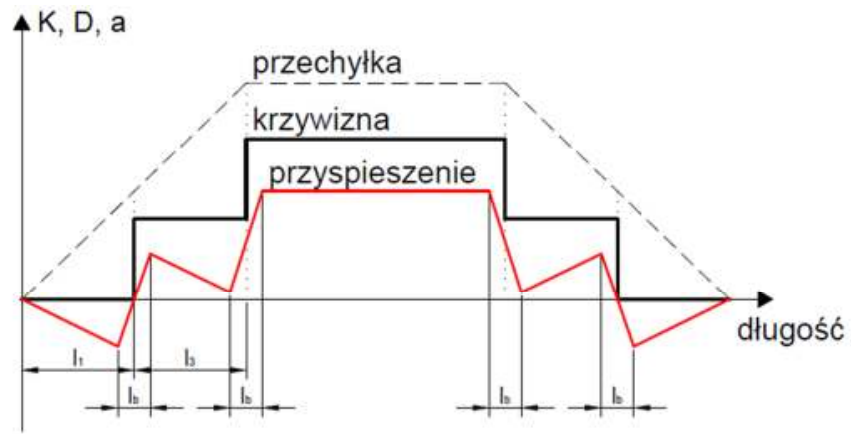

5. Diagram of the variability of parameters on an arc with cant and transition curves in the form of arches with gradually decreasing radii

It should be noted that the system constructed in this way may consist of a much larger number of transition arches than presented in the Polish Guidelines. For example, in the Australian guidelines, there is a basket transition curve, consisting of up to 11 transition arches with gradually decreasing radii [19]. It was determined that it is possible to record general relationships enabling the calculation of acceleration values at individual points, and acceleration increases at individual sections. There are two sections analyzed, the section where the acceleration gradually decreases due to the cant increase at a constant arc radius, and the section where the acceleration increases abruptly (rigid base of the wagon). The minimum value of unbalanced acceleration in each of the ranges is:

$$
-a_{t} \leq a_{x}=\frac{V^{2}}{12,96 R_{(k-1)}}-\frac{g D \sum_{i=1}^{k} L_{(i)}}{s \sum_{i=1}^{n} L_{(i)}} \leq a_{p}
$$

The maximum value of unbalanced acceleration in each of the ranges is:

$$
-a_{t} \leq a_{x}=\frac{V^{2}}{12,96 R_{(k)}}-\frac{g D \sum_{i=1}^{k} L_{(i)}}{s \sum_{i=1}^{n} L_{(i)}} \leq a_{p}
$$

The acceleration increase over time, along the length of the transition arches and the length of the cant ramp on a straight section is:

$$
\left(\frac{d a_{x}}{d t}\right)_{r}=\frac{V g D}{3,6 s \sum_{i=1}^{n} L_{(i)}} \leq\left(\frac{d a}{d t}\right)_{d o p}
$$

The acceleration increase over the length of the rigid base of the wagon at the tangential connection between sections with different curvatures is:

$$
\left|\frac{d a_{x}}{d t}\right|_{b}=\frac{V^{3}}{46,656 R_{(k+1)} L_{b}}-\frac{V^{3}}{46,656 R_{(k)} \square} \leq\left|\frac{d a}{d t}\right|_{\text {dop }}
$$

\section{Determination of the rigid base length in multi-articulated low-floor trams}

The dependencies presented in the previous chapter regarding the increase in unbalanced acceleration result directly from the calculation methodology adopted in railways. According to the railway regulations [3], the length of the rigid base of the wagon $L_{b}$ is taken as the distance between the pivots of the wagon bogies. This approach can be applied directly to the analysis of geometrical systems on which multi-wagon tram-trains consisting of wagons based on rotary bogies run (e.g. 105N and derivatives). In such vehicles, the construction of 
the wagon allows an unequivocal determination of such a distance, which is $6 \mathrm{~m}$. Meanwhile, the Technical Requirements of Warsaw Trams set the length of the rigid base design at $10 \mathrm{~m}$ [17]. In [16] it was determined that for a rigid base of $6 \mathrm{~m}$ length, tangentially connecting straight lines with arches is possible if the arc radius for a given travel speed is not less than given in Table 1. The values are presented for an acceleration increase of $1 \mathrm{~m} / \mathrm{s}^{3}$. This is the maximum permissible value for railway regulations [3] as well as for tramways in Poland and the world $[1,17,18]$. Designing infrastructure with the assumption of maximum values of acceleration increases, however, causes jerks felt by passengers, therefore it is recommended to take values smaller than $0,5 \mathrm{~m} / \mathrm{s}^{3}$.

Tab. 1. Minimum arc radius values allowing connection with a straight line without a transition curve for $\mathrm{L}_{b}=6 \mathrm{~m}$

\begin{tabular}{|c|c|c|c|c|}
\hline & $V=40 \mathrm{~km} / \mathrm{h}$ & $V=50 \mathrm{~km} / \mathrm{h}$ & $V=60 \mathrm{~km} / \mathrm{h}$ & $V=70 \mathrm{~km} / \mathrm{h}$ \\
\hline$R_{\min }$ & $300 \mathrm{~m}$ & 500 & 800 & 1400 \\
\hline
\end{tabular}

A comfortable ride at the speeds allowed by the design conditions of the $105 \mathrm{~N}$ tram is hindered by the small arc radii typical of tram routes and the lack of transition curves. 105N wagons and derivatives are, however, high-floor constructions and are now obsolete, which are successively replaced by modern low-floor multi-articulated trams. Modern vehicles have a definitely different construction, not reminiscent of typical rail vehicles. The first low-floor tram, Alstom TFS-1, consisted of three components based on rotary bogies [14]. It was created based on a high-floor, articulated streetcar with a Jacobs rolling bogie. Determining the length of the rigid base for such a tram is not a major problem and is approximately $6 \mathrm{~m}$ (as for the $105 \mathrm{~N}$ wagon). Currently, however, such structures are being moved away (due to the lack of a low floor along the entire length of the train) and trams of completely different construction are being produced. The most frequently purchased trams in Poland today are multi-articulated carriages modeled on the Combino modular tram [15]. They consist of two types of elements: elements based on a rigid carriage and elements hanging between supported elements. Trams can be entirely low-floor, without transverse steps and ramps (such as Pesa Jazz), they are also relatively uncomplicated and inexpensive. The great operational difficulty of these vehicles is due to the use of rigid trucks (without the possibility of free circulation). When the vehicle moves along a curvature, along with the rotation of the bogie, the entire support element rotates.

In a multi-articulated tram, two zones with different lengths of rigid bases can be distinguished:

- The first zone is located in leaning elements, characterized by sudden jerks. The rotation of the supporting element is minimally reduced by springing in relation to the trolley, however, with the same operating conditions (speed, radius, length and type of transition curve) passengers experience significantly greater jerks than when traveling by tram with rotary bogies. These elements lack the possibility to determine the length of the rigid base (according to railway rules). In the literature, analyzes are showing that in the case of rigid trucks, the length of the rigid base is calculated based on the wheelbase of the axle $(1.9 \mathrm{~m})$ [11]. Since the bogies in the analyzed trams are not completely rigid and have the possibility of a small turn, the observed values of acceleration increases were smaller than would appear from the calculations. Comparative analysis (using MEMS accelerometers in the Pesa Swing and N8C tram) allowed to determine that the calculated rigid base for such a zone is about 4 $\mathrm{m}[13]$.

- The second zone is located in the hanging members, where the jerks are not that perceptible compared to a ride on a classic tram. This is due to the fact that the rigid base for 
these elements refers to the distance between the centers of Hubner's passages (joints with the possibility of movement in two planes) and is often longer than for $105 \mathrm{~N}$ wagons.

\section{Calculation of kinematic parameters for low-floor trams}

Currently, an intensive rolling stock replacement process is underway in Poland. Cities are moving from the operation of wagon vehicles to multi-articulated low-floor trams. Most often, it is planned to maintain operational parameters (or improve them due to the increase in speed) on the unchanged geometrical system of tracks adapted to running trams on rotary trucks. As shown earlier, the lengths of rigid bases (and thus acceleration increases) differ significantly between modern and classic constructions. For this reason, after the introduction of new trams, it is very common for passengers to say that the vehicles are undoubtedly comfortable, but they pull hard when driving. At the same time, passengers not realizing the variability of travel conditions in different parts of the tram, most often blame the driver for reduced driving comfort. For this reason, it was decided to calculate acceleration increases on systems designed by the Guidelines [7], assuming a rigid base length of $4 \mathrm{~m}$ (as for an element based on a multi-articulated tram). For arches with a radius below $100 \mathrm{~m}$, calculations were made assuming that the transition curves are designed in the form of tangential arches (with a cant ramp not related to the length of the transition arches), and for arches with a larger radius without a transition curve. Table 2 shows the maximum acceleration increase values for a given system calculated for the minimum cant. The values given for normal cant are comparable, but the calculation range would be reduced (lower maximum speed). Values exceeding $1 \mathrm{~m} / \mathrm{s} 3$ (maximum permissible value) are marked in black, and values exceeding $0.5 \mathrm{~m} / \mathrm{s} 3$ (value above which passengers experience a decrease in driving comfort) are marked in light gray. It should be noted that only when adopting the permissible acceleration increase value of $1 \mathrm{~m} / \mathrm{s} 3$, it is possible to drive low-floor trams at a speed of $70 \mathrm{~km} / \mathrm{h}$, on geometric layouts designed according to the Guidelines [7].

Tab. 2. Maximum acceleration increase value due to the arc speed and radius

\begin{tabular}{cccccccccc}
$\mathrm{V}[\mathrm{km} / \mathrm{h}]$ & 10 & 15 & 20 & 25 & 30 & 40 & 50 & 60 & 70 \\
$\mathrm{R}[\mathrm{m}]$ & & & & & & & & & \\
20 & 0,161 & 0,504 & 1,232 & & & & & & \\
25 & 0,107 & 0,323 & 0,804 & & & & & & \\
30 & 0,071 & 0,202 & 0,520 & 1,048 & & & & & \\
35 & 0,054 & 0,181 & 0,429 & 0,701 & & & & & \\
40 & 0,054 & 0,181 & 0,429 & 0,701 & 1,284 & & & & \\
50 & 0,054 & 0,181 & 0,429 & 0,772 & 1,365 & & & & \\
75 & 0,036 & 0,121 & 0,286 & 0,558 & 0,883 & 2,178 & & & \\
100 & 0,054 & 0,181 & 0,429 & 0,837 & 1,369 & 3,322 & & & \\
150 & 0,036 & 0,121 & 0,286 & 0,558 & 0,965 & 2,182 & 4,331 & 7,555 & \\
200 & 0,027 & 0,090 & 0,214 & 0,419 & 0,723 & 1,715 & 3,219 & 5,624 & 9,000 \\
300 & 0,018 & 0,060 & 0,143 & 0,279 & 0,482 & 1,143 & 2,233 & 3,702 & 5,944 \\
400 & 0,013 & 0,045 & 0,107 & 0,209 & 0,362 & 0,857 & 1,674 & 2,894 & 4,413 \\
500 & 0,011 & 0,036 & 0,086 & 0,167 & 0,289 & 0,686 & 1,340 & 2,315 & 3,676 \\
750 & 0,007 & 0,024 & 0,057 & 0,112 & 0,193 & 0,457 & 0,893 & 1,543 & 2,451 \\
\hline
\end{tabular}




$\begin{array}{lllllllllll}1000 & 0,005 & 0,018 & 0,043 & 0,084 & 0,145 & 0,343 & 0,670 & 1,157 & 1,838 \\ 2000 & 0,003 & 0,009 & 0,021 & 0,042 & 0,072 & 0,171 & 0,335 & 0,579 & 0,919\end{array}$

\section{Conclusions}

Comfort disturbance on curves is due to the lack of transition curves or their insufficient length. In the absence of curves, or when arrays with gradually decreasing radii are used, the unbalanced acceleration increases along the length of the rigid base of the wagon. At higher travel speeds, the very short bases of modern low-floor tram wagons are of insufficient length to ensure acceptable travel comfort.

Putting into operation modern low-floor trams should take place simultaneously with the process of adapting the infrastructure to the increased speed of new trams compared to the old ones and differences in cooperation between the track and the vehicle. Vehicles with rigid support for elements on bogies (or providing the possibility of a small turn), in analyzes should be treated as if the length of the rigid base of the wagon was very short (proposed design length $4 \mathrm{~m}$ ).

The use of simplified geometrical systems, without transition curves and with cant ramps located on straight sections in front of the arches should be abandoned, as they do not ensure gentle increases of unbalanced acceleration. If it is possible, arches should be designed preceded by transition curves in the form of a clothoid of appropriate length. If it is not possible to enter transition curves (e.g. at switches), the principle of calculating the actual kinematic parameters should be introduced and speed restrictions should be applied as required.

If it is not possible to adapt the infrastructure to the operation requirements of trams with a very short calculated length of the rigid base of the wagon, consideration should be given to formulating tender conditions for the purchase of new wagons so that new vehicles will have longer base lengths. This can be achieved by establishing the appropriate structure of the bogies (all rotating bogies) and their arrangement along the length of the wagon (in equal distances). An example of such constructions can be trams purchased by Krakow, e.g. Bombardier NGT8 or Pesa Krakowiak, which, despite the higher price, are characterized by higher traction properties and gentler fitting in the arches.

\section{Symbols}

$$
\begin{aligned}
& a-\text { acceleration }[\mathrm{m} / \mathrm{s} 2] \\
& a_{x}-\text { unbalanced acceleration }[\mathrm{m} / \mathrm{s} 2] \\
& \frac{d a}{d t}-\text { velocity of unbalanced acceleration increase }\left[\mathrm{m} / \mathrm{s}^{3}\right] \\
& \frac{d D}{d t}-\text { wheel lift speed on the cant ramp }[\mathrm{mm} / \mathrm{s}] \\
& \frac{d D}{d s}-\text { steepness of the cant ramp }[\mathrm{mm} / \mathrm{m}] \\
& D-\text { cant }-[\mathrm{mm}] \\
& g-\text { gravitational acceleration }\left[\mathrm{m} / \mathrm{s}^{2}\right] \\
& k-\text { the number of considered transition arch } \\
& L-\text { length of the transition curve }[\mathrm{m}] \\
& L_{b}-\text { length of wagon's rigid base }[\mathrm{m}] \\
& n-\text { number of transition arches } \\
& R \text { - radius of the arc }[\mathrm{m}]
\end{aligned}
$$




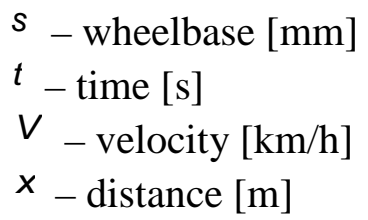

\section{Source materials}

[1] Der Schweizerische Bundesrat: Verordnung über Bau und Betrieb der Eisenbahnen (Eisenbahnverordnung, EBV), 1983

[2] Koc W., Specht C., Nowak A, Szulwic J., Szmagliński J., Skóra M., Specht M., Czapnik M.: Dostępność fazowych rozwiązań GPS/GLONASS podczas geodezyjnej inwentaryzacji dróg szynowych - na przykładzie linii tramwajowej Gdańska, Technika Transportu Szynowego 9/2012.

[3] Dz. U. $1998 \mathrm{nr} 151$ poz. 987: Rozporządzenie Ministra Transportu i Gospodarki Morskiej z dnia 10 września 1998 roku w sprawie warunków technicznych jakim powinny odpowiadać budowle kolejowe i ich usytuowanie

[4] Dz. U. 1999 nr 43 poz. 430, Rozporządzenie Ministra Transportu i Gospodarki Morskiej z dnia 2 marca 1999 r. w sprawie warunków technicznych, jakim powinny odpowiadać drogi publiczne i ich usytuowanie

[5] Koc W., Specht C., Chrostowski P., Szmagliński J.: Możliwości satelitarnej oceny położenia geometrycznego tramwajowych węzłów rozjazdowych. Zeszyty NaukowoTechniczne Stowarzyszenia Inżynierów i Techników Komunikacji w Krakowie, seria: Materiały Konferencyjne, nr 2 (zeszyt 101), Kraków 2013

[6] Koc W., Specht C., Chrostowski P., Szmagliński J.: Ocena kształtu geometrycznego torów tramwajowych na podstawie pomiarów satelitarnych, Prace Naukowe Politechniki Warszawskiej, Transport, 98/2013

[7] Ministerstwo Administracji, Gospodarki Terenowej i Ochrony środowiska, Departament Komunikacji Miejskiej i Dróg: Wytyczne techniczne projektowania, budowy i utrzymania torów tramwajowych, Warszawa 1983

[8] Ministerstwo Administracji, Gospodarki Terenowej i Ochrony Środowiska. Departament Komunikacji Miejskiej i Dróg: Tymczasowe wytyczne do projektowania szybkiej komunikacji tramwajowej, Warszawa 1981

[9] PN-EN 13803-1: 2010: Kolejnictwo - Tor - Parametry projektowania toru w planie Tor o szerokości 1435 mm i większej - Część 1: Szlak

[10] PN-EN 13803-2: 2010: Kolejnictwo - Tor - Parametry projektowania toru w planie Tor o szerokości $1435 \mathrm{~mm}$ i większej - Część 2: Rozjazdy, skrzyżowania i inne porównywalne przypadki z nagłymi zmianami krzywizny

[11] Rychlewski J., Firlik B., Straszewski W.: Wytyczne projektowania torów tramwajowych a obecnie używany tabor tramwajowy, Archiwum instytutu inżynierii lądowej 25/2017

[12] Specht C., Koc W., Nowak A., Szulwic J., Szmagliński J., Skóra M., Specht M., Czapnik M.:

[13] Szmagliński J.: Projektowanie tras tramwajowych przy wykorzystaniu mobilnych pomiarów satelitarnych, Archiwum instytutu inżynierii lądowej 25/2017

[14] Szmagliński J.: Tramwaje niskopodłogowe. Geneza, konstrukcje, Infrastruktura Transportu 4/2014

[15] Szmagliński J.: Tramwaje niskopodłogowe w Polsce, Infrastruktura Transportu 6/2014.

[16] Szwaczkiewicz K., Szmagliński J.: Propozycja wykorzystania praktyki kolejowej przy modernizacji torów tramwajowych, Logistyka 4/2015 
[17] Tramwaje Warszawskie: Wymagania techniczne dotyczące projektowania i budowy torowisk tramwajowych na sieci Tramwajów Warszawskich, 2016.

[18] Transit Cooperative Research Program: Track Design Handbook for Light Rail Transit, Washington D.C. 2012.

[19] Yarra Trams, Tram track design guidelines, Melbourne 2003. 